\title{
Notes on the vocalizations of Large Cuckoo-shrike (Coracina macei) and Javan Cuckoo-shrike (Coracina javensis)
}

\section{Peter Boesman}

In the following we briefly analyze and compare voice of the different races of Large Cuckooshrike (Coracina macei) and Javan Cuckoo-shrike (Coracina javensis). We also try to quantify the extent of any vocal differences using the criteria proposed by Tobias et al. (2010), as a support for taxonomic review. We have made use of sound recordings available on-line from Xeno Canto (XC) and Avian Vocalizations Center (AVoCet).

We have found only a few recordings of macei and a single (poor quality) one of race layardi. We compare here the commonly heard call of the different races:

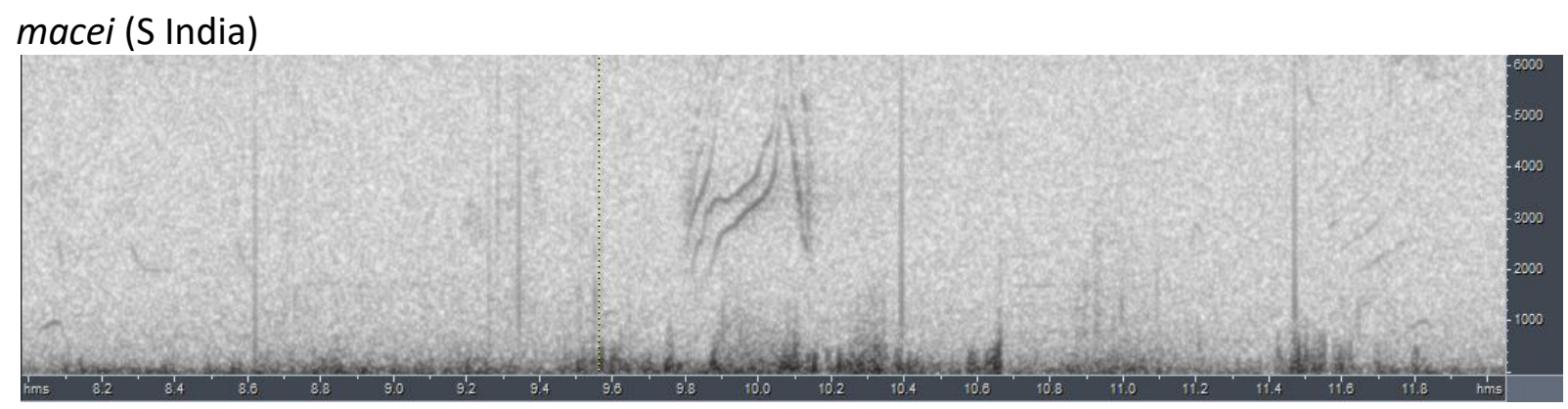

macei (Goa, India)

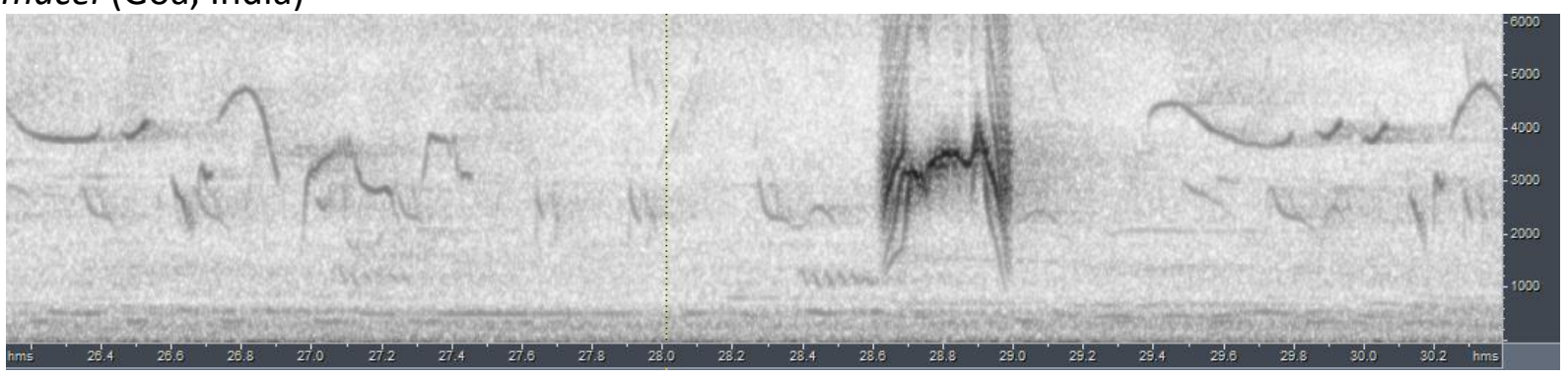

macei (Thana, India)

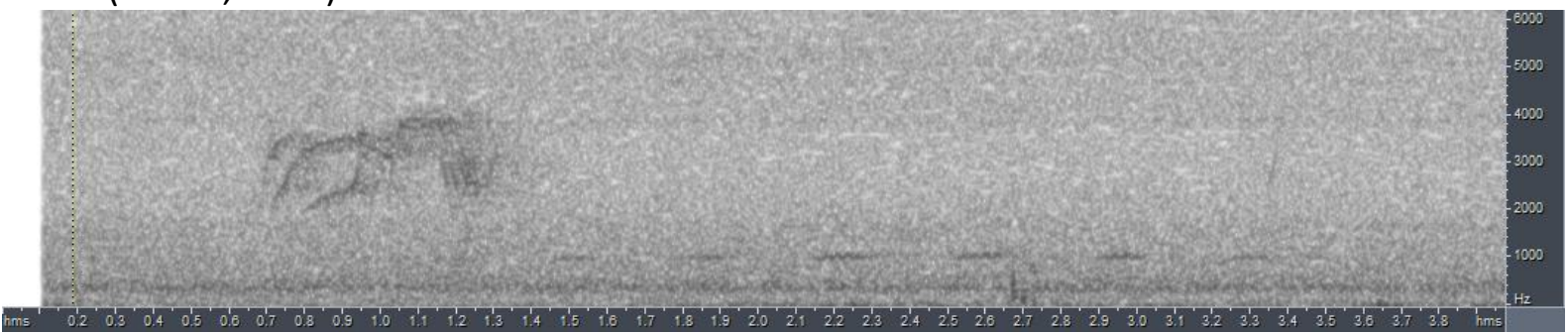

macei ? (W Bengal,India)

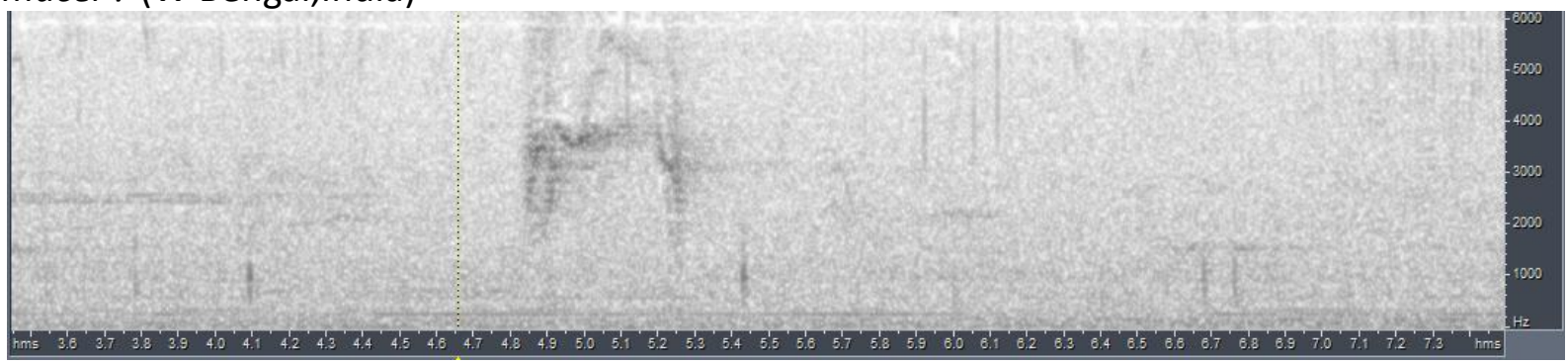




\section{HANDBOOK OF THE BIRDSPF THE WORLD Alve}

\section{ORNITHOLOGICAL NOTES}

\section{layardi (Sri Lanka)}

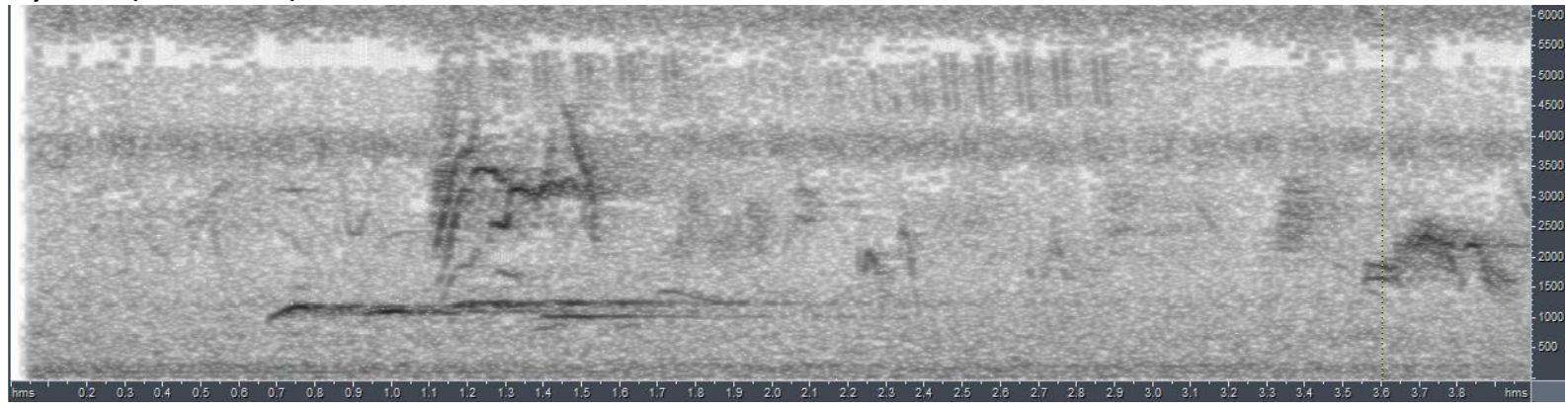

nipalensis (Assam, India)

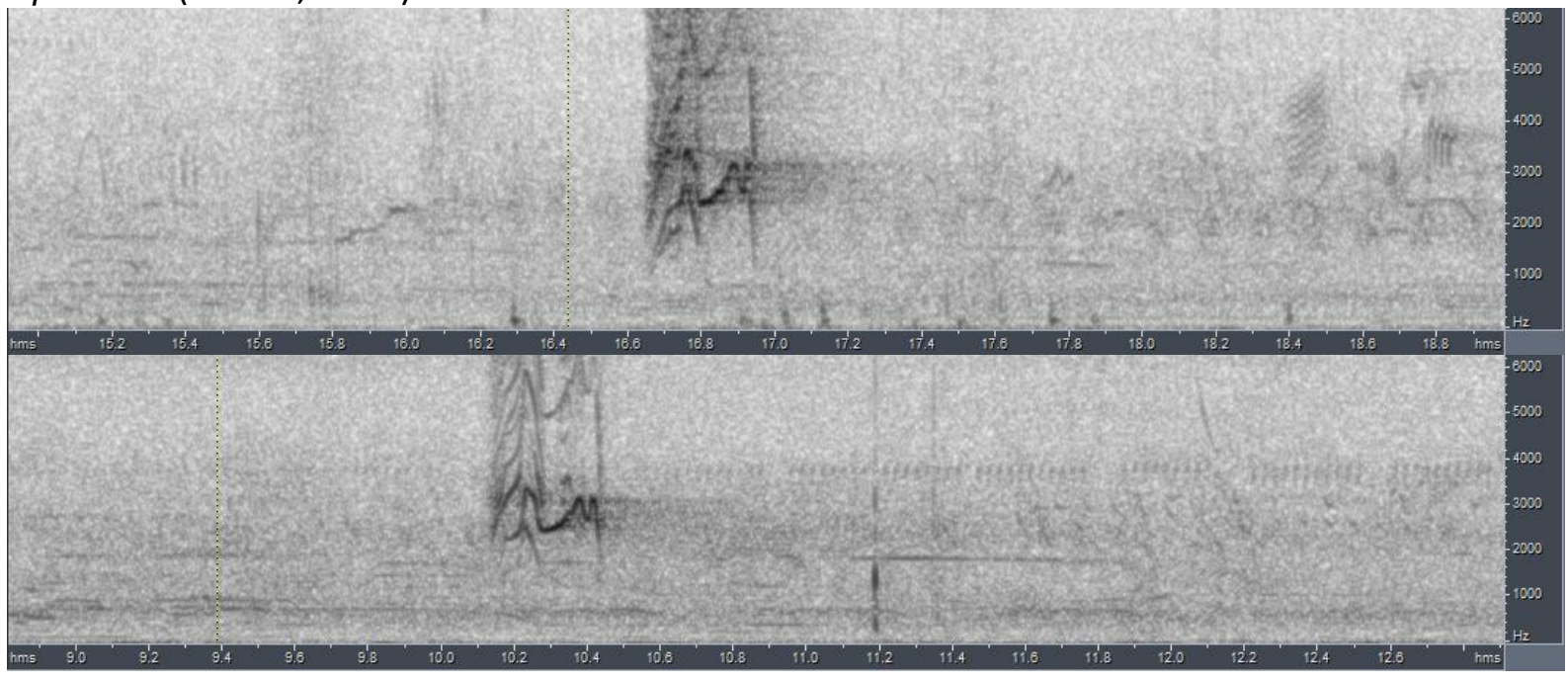

siamensis (Myanmar)

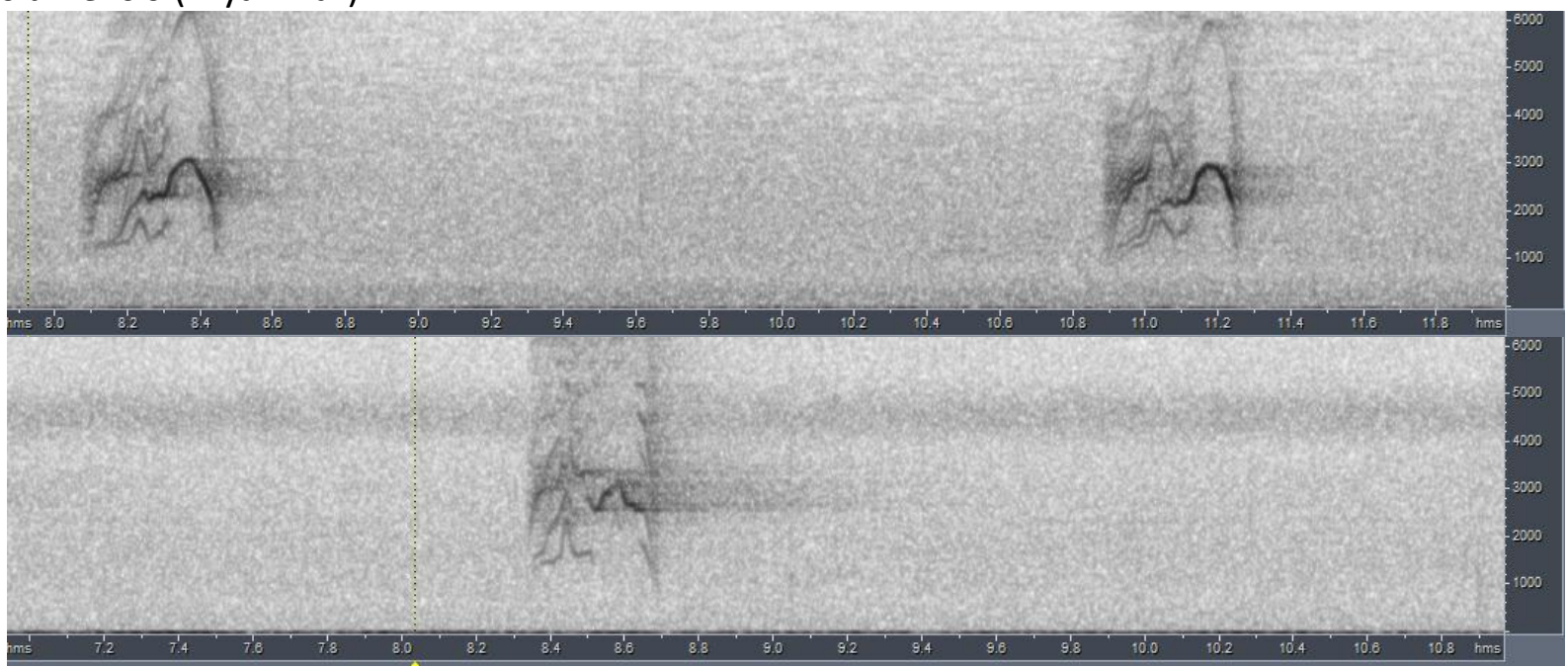

siamensis (Thailand)

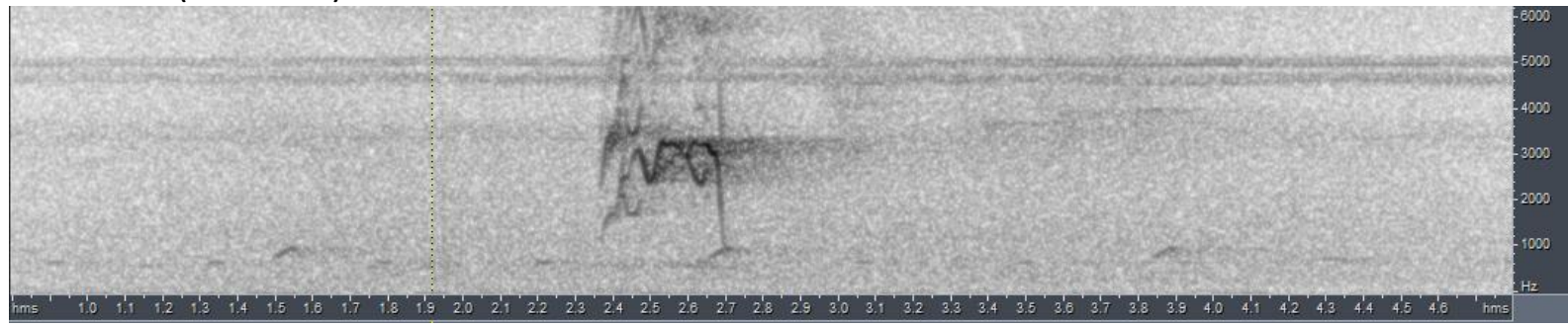




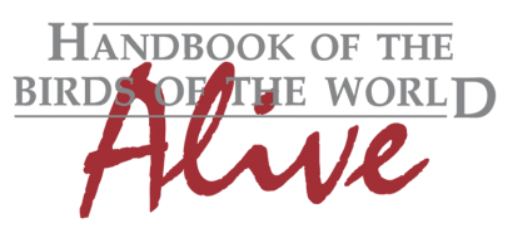

\section{ORNITHOLOGICAL NOTES}

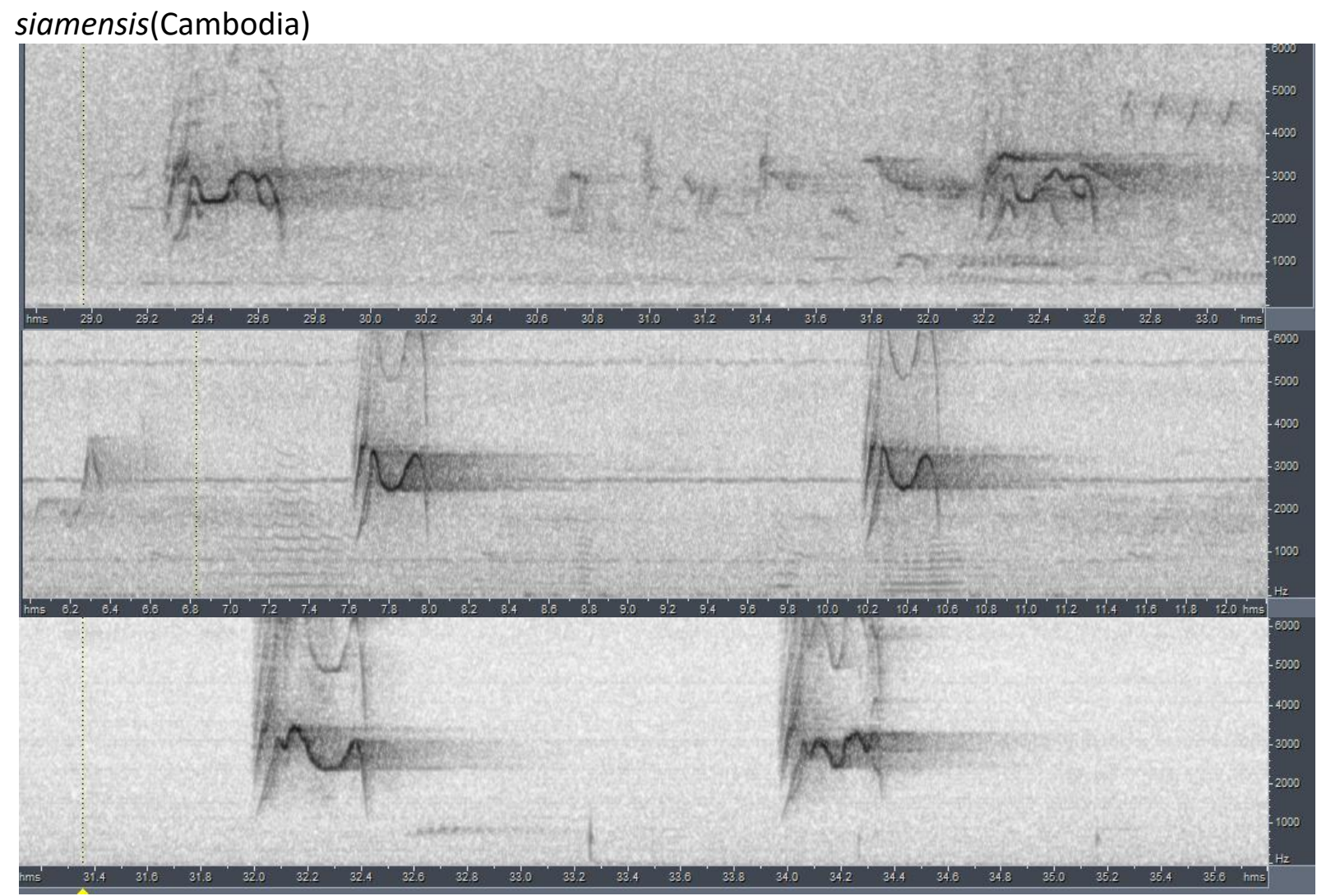

siamensis (Vietnam)

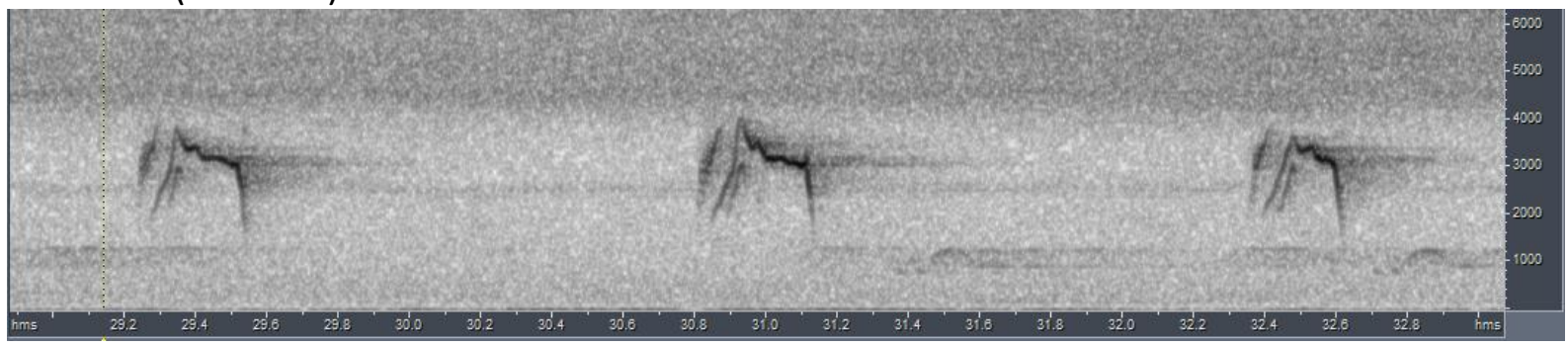

\section{rexpineti (Taiwan)}

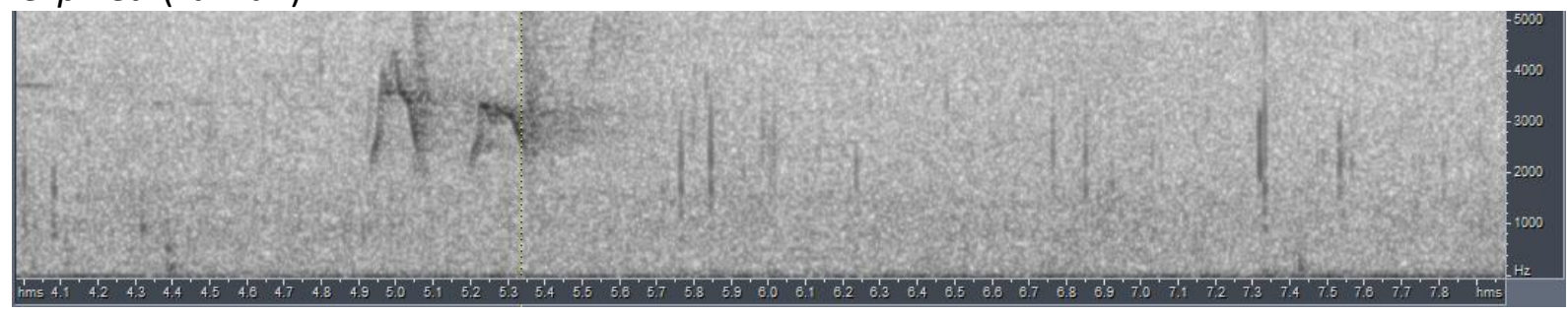

larutensis (Peninsular Malaysia)

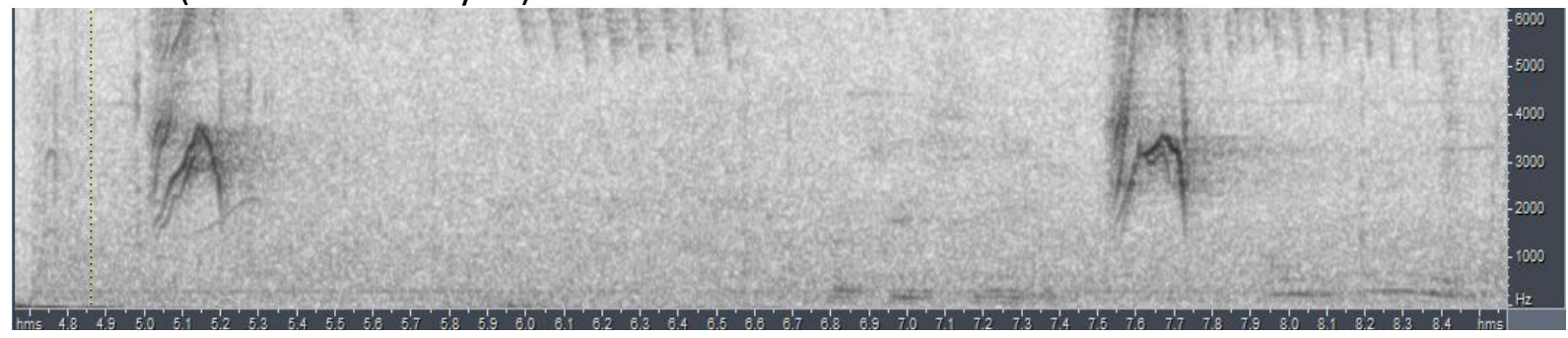



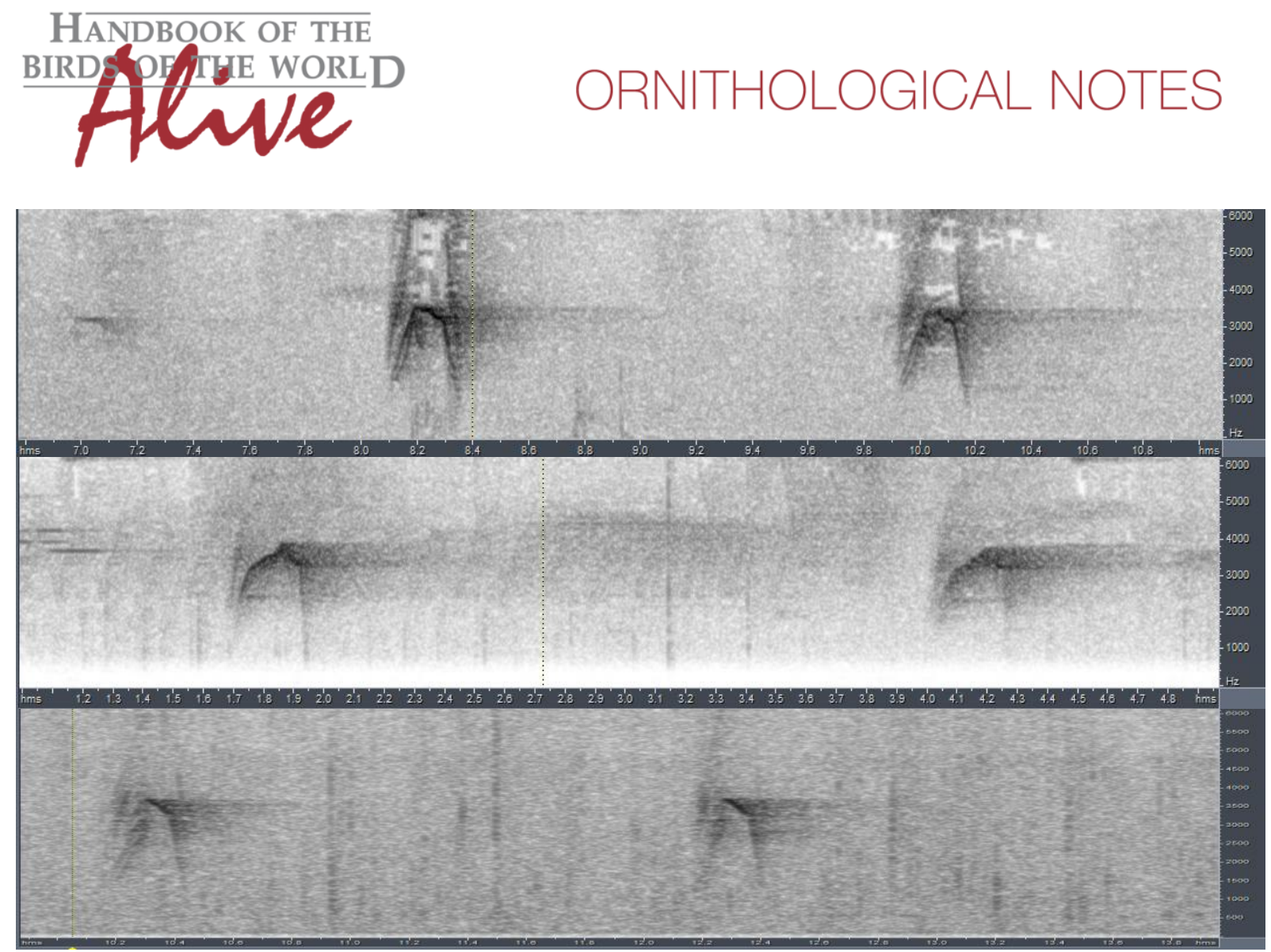

Rasmussen and Anderton (2012) state that macei/layardi has a longer call and lacks ending downturn. We can't confirm this, as illustrated in the above samples.

We measured:

macei:

$$
\begin{array}{ll}
\text { length } & 0.34-0.52 \mathrm{~s} \\
\text { max. freq. } & 4000-5700 \mathrm{~Hz}
\end{array}
$$

other races (excl. rexpineti/larutensis)

$$
\begin{array}{ll}
\text { length } & 0.30-0.44 \mathrm{~s} \\
\text { max. freq. } & 3000-3500 \mathrm{~Hz} \text { (with aberrant call from Vietnam reaching } 3800 \mathrm{~Hz} \text { ) }
\end{array}
$$

If we assume that layardi has similar voice as macei (as suggested by the single recording we have), then this group is clearly different from nipalensis/siamensis in reaching higher frequencies (score 2-3) and having a predominantly rising note shape (vs. fairly flat or up and down plateau in nipalensis/siamensis)(score 1)

When applying Tobias criteria, this would lead to a total vocal score for macei/layardi vs. nipalensis/siamensis of 3-4.

rexpineti: it would seem that this vocalization is closer to Bar-bellied Cuckoo-shrike Coracina striata. (The description in Brazil (2009) confirms its double-noted call, ID is thus reliable). It is unclear whether rexpineti from mainland China also has a double call or not.

larutensis: call is clearly different from all other races: shorter and simpler, rather symmetrically overslurred.

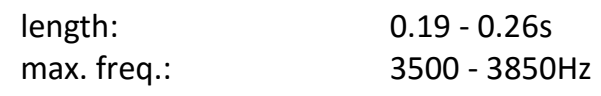



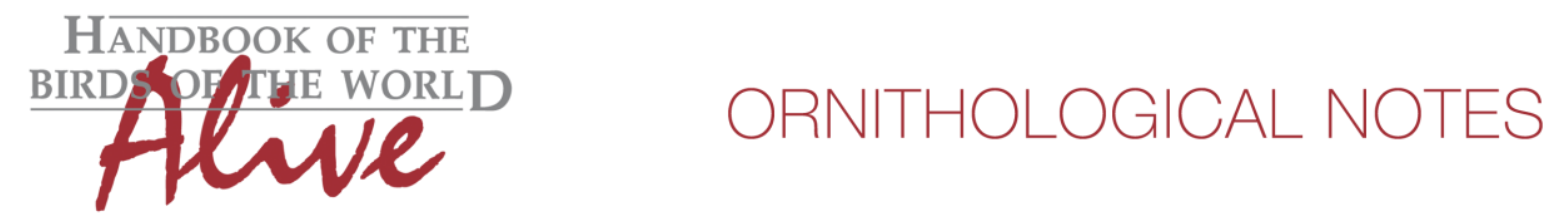

If we compare larutensis with Javan Cuckooshrike (two recordings of javensis found):
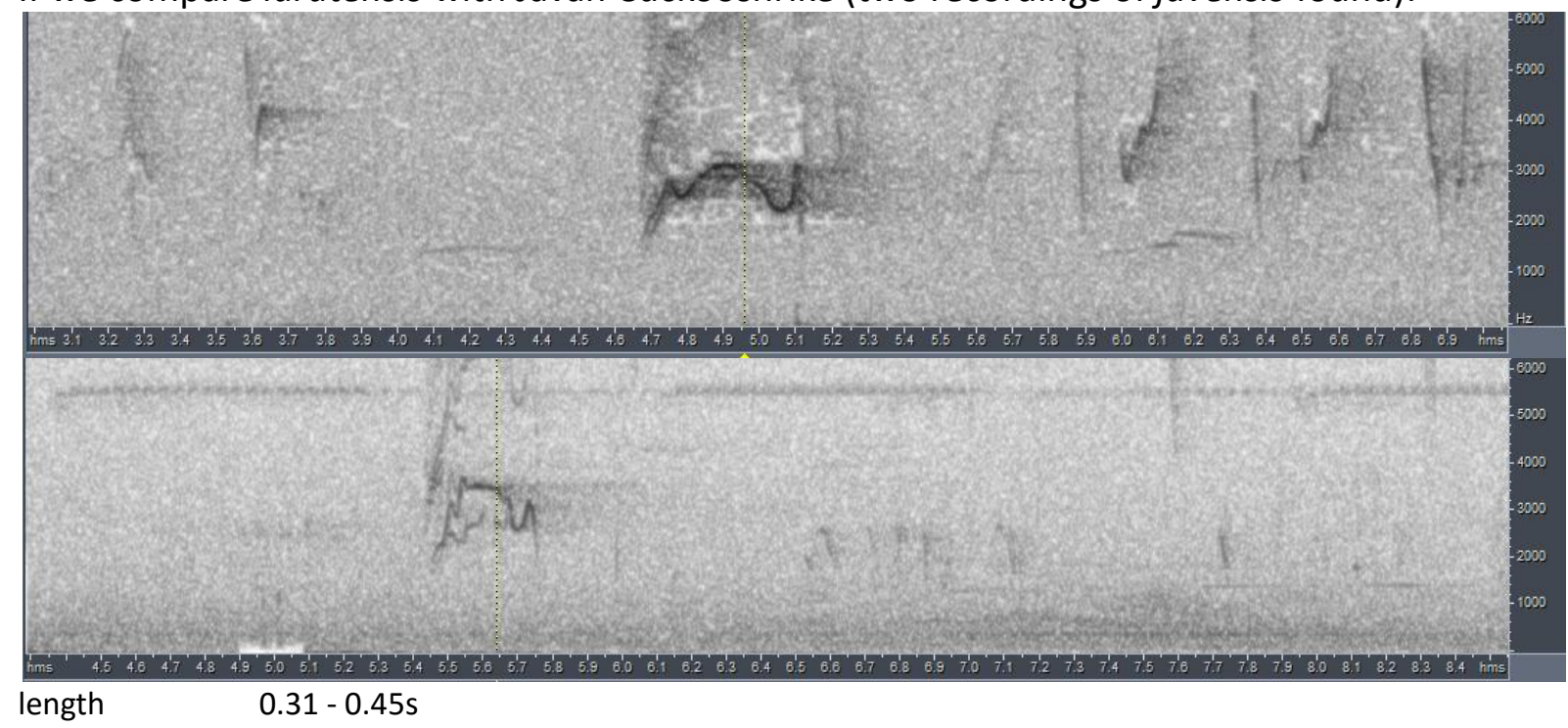

max. freq. $\quad 3200-3700 \mathrm{~Hz}$

it would seem that vocally javensis is closer to nipalensis/siamensis than to larutensis (!). larutensis is clearly different from both javensis and nipalensis/siamensis .

\section{Conclusion:}

* macei/layardi vs. nipalensis/siamensis are vocally moderately distinct: score 3-4.

* larutensis is different from all races, including $C$. javensis: score about 4 (this supports the suggestion by some that this taxon is a distinct species Malaysian Cuckoo-shrike)

* rexpineti from Taiwan has a voice more like $C$. striata, but voice from mainland China unknown.

This note was finalized on 4th November 2015, using sound recordings available on-line at that moment. We would like to thank in particular the sound recordists who placed their recordings for this species on XC and AVoCet: Marc Anderson, Peter Boesman, David Edwards, David Farrow, Greg Irving, Frank Lambert, Ruey-Shing Lin, Martjan Lammertink, Andrew Mascarenhas, Sushant More, Mike Nelson, Ding Li Yong and Deepal Warakagoda.

\section{References}

Brazil, M. (2009). Field guide to the Birds of East Asia. Christopher Helm. London.

Rasmussen, P.C. \& Anderton, J.C. (2012). Birds of South Asia: the Ripley Guide. Vols. 1-2. 2nd edition. National Museum of Natural History, Smithsonian Institution, Michigan State University \& Lynx Edicions, Washington, D.C., Michigan \& Barcelona. 


\section{Recommended citation}

Boesman, P. (2016). Notes on the vocalizations of Large Cuckoo-shrike (Coracina macei) and Javan Cuckoo-shrike (Coracina javensis). HBW Alive Ornithological Note 176. In: Handbook of the Birds of the World Alive. Lynx Edicions, Barcelona. (retrieved from http://www.hbw.com/node/932111 on 22 August 2016). 